\title{
Esophagoduodenoscopy or colonoscopy: which should be done first?
}

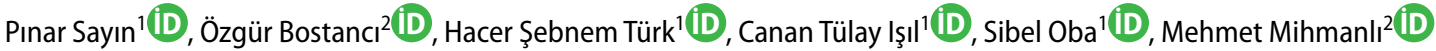 \\ 1 Department of Anestesiology and Reanimation, Sisli Hamidiye Etfal Training and Research Hospital, Istanbul, Turkey \\ ${ }^{2}$ Department of General Surgery, Sisli Hamidiye Etfal Training and Research Hospital, Istanbul, Turkey
}

\begin{abstract}
Objective: Esophagoduodenoscopy and colonoscopy can be done as bidirectional endoscopy in the same session. The aim of this study was to compare anesthetic requirements and hemodynamic effects in esophagoduodenoscopy or colonoscopy done first for bidirectional endoscopy.

Material and Methods: Eighty patients, aged 18-70 years with an American Society of Anesthesiologists Classification (ASA) as I-III, were included randomly into this study. The patients were allocated into two groups: Group C: first colonoscopy followed by esophagoduodenoscopy. Group E: first esophagoduodenoscopy followed by colonoscopy. All patients received standard anesthesia with $1 \mu \mathrm{g} / \mathrm{kg}$ fentanyl and $1 \mathrm{mg} / \mathrm{kg} \mathrm{propofol}$. Demographical variables, Heart rate $\mathrm{SpO}_{2}$, Ramsey Sedation Score were recorded every 10 minutes. Total propofol consumption, retching during esophagoduodenoscopy and time to reach cecum were also recorded. Endoscopist and patient satisfaction were questioned.

Results: Retching during esophagoduodenoscopy was not statistically significantly different in both groups. Total procedure duration and esophagoduodenoscopy duration were statistically significant longer in Group E. Complication frequency was higher in Group E. Endoscopist and patient satisfaction were lower in Group E. There was no difference in time to reach the cecum and the recovering period. Additional propofol dose was increased in Group $\mathrm{E}$.

Conclusion: Regarding shorter procedural duration, lower consumption amount of propofol and fewer complications, it could be a better choice to start bidirectional procedure with colonoscopy first.
\end{abstract}

Keywords: Colonoscopy, gastroscopy, anesthesia, patient satisfaction.

Cite this article as: Sayın P, Bostancı Ö, Türk HŞ, Ișıl CT, Oba S, Mihmanlı M. Esophagoduodenoscopy or colonoscopy: which should be done first?. Turk J Surg 2020; 36 (2): 172 179.

Corresponding Author

Hacer Şebnem Türk

E-mail: hacersebnem@yahoo.com.tr

Received: 26.11 .2018

Accepted: 27.05 .2019

Available Online Date: 08.06 .2020

O Copyright 2020 by Turkish Surgical Society Available online at www.turkjsurg.com

DOI: $10.5578 /$ turkjsurg. 4275

\section{INTRODUCTION}

Bidirectional endoscopy (BE) consists of esophagoduodenoscopy (EDS) and colonoscopy, which are done at the same session on the same day. BE is an important tool to diagnose nonspecific symptoms as iron deficiency, positive fecal occult blood test, suspected gastrointestinal system (GIS) malignancy, stomachache, abdominal distention and weight loss $(1,2)$. Completing the procedure in the same session shortens not only hospital stay, but also reduces risks related to anesthesia (3). Usually, it is the endoscopist's choice from which side to start, EDS or colonoscopy. There is still no agreement between the endoscopists on whether to begin bidirectional endoscopy from EDS or colonoscopy first (4-6).

Nowadays, sedation is preferred for endoscopic procedures (7). Propofol application watched by an anesthesiologist for sedation provides a fast onset time and fast recovery in comparison to other anesthetic drugs (8).

The aim of this study was to determine whether EDS or colonoscopy should be done first, and as a result, to determine the optimal order for BE.

\section{MATERIAL and METHODS}

This study was a prospective, randomized and controlled study, which started after receiving local ethics committee approval (28.05.2013/197) and obtaining patient's informed consent in our Endoscopy Unit, and it was completed in a 6-month period.

Eighty patients scheduled for BE aged 18-70, with an American Society of Anesthesiologists Classification (ASA) as I-III, were included in this study. 
Patients with active GIS bleeding, severe cardiac and respiratory failure, propofol or fentanyl allergy, alcohol or drug addiction, neuropsychiatric disease, suspicious of difficult airway and patients, who could not complete the screening because of inadequate colon cleaning or obstruction because of colon cancer were excluded.

The patients were allocated randomly in two groups via the closed envelope technique. Group C patients underwent the colonoscopy procedure first, then the EDS procedure. Group $G$ patients underwent EDS procedure first and afterwards, the colonoscopy procedure. All endoscopic interventions were done by the same two endoscopists.

For endoscopic procedures (Olympus ${ }^{\circledR}$ EVIS EXERA Video Gastroscope GIF-160; Olympus Switzerland AG, Volketswil 8604, Switzerland) endoscope and Olympus ${ }^{\circledR}$ CF Q160L///S; Olympus Switzerland AG, Volketswil 8604, Switzerland) colonoscopes were used. Insufflation was done with room air. Prior to each procedure, disinfection and drying were carried out after mechanical cleaning of the gastroscope and colonoscopes on separate washing machines. Endoscopists wore protective equipment such as aprons and gloves before the procedure. They changed their aprons and gloves when they passed from gastroscopy to colonoscopy and from colonoscopy to gastroscopy.

Patients were advised to starve for a 12-hour period, to take laxatives the day before endoscopy appointment and to administer enema for gut cleaning. Patients were also warned not to take alcohol or any sedative drugs.

Patient's informed consent was obtained when the patient was admitted on the day of endoscopy. All procedures were performed in the endoscopy unit. All patients were inserted an intravenous (IV) catheter sized 22 Gauge and transfused $0.9 \% \mathrm{NaCl}$. Then they were prepared for the endoscopy procedure in a lateral decubitus position and monitored with electrocardiography, noninvasive blood pressure measuring and pulse oximetry. Oxygen supply was provided by a nasal cannula with a flow of 3-4 L/ minute oxygen. Initial heart rate $(\mathrm{HR})$ and saturation $\left(\mathrm{SpO}_{2}\right)$ were recorded. All patients received premedication with $1 \mathrm{mg}$ midazolam (Dormicum ${ }^{\oplus ;}$ DEVA pharm, Istanbul, Turkey) intravenously. The oropharyngeal was topically anesthetized with 3 puffs of lidocaine 10\% (Xylocain ${ }^{\circledR}$ 10\% spray; AstraZeneca, Istanbul, Turkey) spray. Deep sedation was provided by the same two anesthetists with $1 \mathrm{mcg} / \mathrm{kg}$ fentanyl citrate (Fentany ${ }^{\circledR}$ amp; Abott laboratories, North Chicago, USA) and $1 \mathrm{mg} / \mathrm{kg}$ propofol 1\% (Propofol ${ }^{\circledR}$ 1\%; Fresenius, Graz, Austria). Sedation depth was achieved to be Ramsey Sedation Score (RSS, Appendix 1). Additional propofol doses of $0.5 \mathrm{mg} / \mathrm{kg}$ were given when RSS was under 3 and recorded. RSS scores were also recorded during the procedure.

Demographic variables as age, sex, weight, height, and ASA score were recorded. $\mathrm{HR}, \mathrm{SpO}_{2}$ and RSS were recorded every 10

\begin{tabular}{|c|c|}
\hline \multicolumn{2}{|l|}{ Appendix 1. Ramsey Sedation Score (RSS) } \\
\hline Definition & Score \\
\hline Patient is anxious and agitated or restless, or both & 1 \\
\hline Patient is cooperative, oriented and tranquil & 2 \\
\hline Patient responds to commands only & 3 \\
\hline $\begin{array}{l}\text { Patient exhibits brisk response to light glabellar tap or } \\
\text { loud auditory stimulus }\end{array}$ & 4 \\
\hline $\begin{array}{l}\text { Patient exhibits a sluggish response to light glabellar tap } \\
\text { or loud auditory stimulus }\end{array}$ & 5 \\
\hline Patient exhibits no response & 6 \\
\hline
\end{tabular}

minutes. Retching during EDS, identification of a tumor or polyp, success in reaching the cecum, and if successful in reaching the cecum, time to reach the cecum were recorded.

Total procedure duration was the time from beginning of anesthesia induction until end of BE procedure. Total procedure duration, EDS and colonoscopy durations, additional preparation time including time from the end of a procedure until the beginning of the next procedure were recorded. Complications related to the interventions or to anesthetic management were recorded all over the procedure duration and recovery period. Recovery period was defined as time from beginning of anesthesia induction to recovery to Aldrete score 9 (Appendix 2). Endoscopist's and patient's satisfaction were evaluated with a visual analog scale (VAS) score (1: very bad, 10: very good). When patients received an Aldrete score of 9, they were transported to the recovery room and observed for one hour before discharge.

\section{Statistical Analysis}

Statistical analyses were made with NCSS (Number Cruncher Statistical System, 2007, Statistical Software, Utah, USA) package program. Descriptive statistics for mean \pm standard deviation, repeated analysis of variants for repeated measurements of multiple groups, Newman Keuls multiple comparison test for subgroup comparisons, Student t-test fort two group comparisons, Chi-Square and Fisher Exact test for qualitative data comparisons were used for statistical analyzes. Results were accepted as statistically significant when $p<0.05$.

\section{RESULTS}

Totally 80 patients of ASA I-III, aged between 18-70 years, scheduled for BE were included in this study (Appendix 3). There was no statistically significant difference in demographical data between the groups. Frequency of retching at the oropharyngeal placement of the endoscope was not statistically significant different between the groups. Colonoscopy duration was not statistically significant different between the groups $(p=0.131)$. EDS was prolonged in Group G (3.22 \pm 1.31 for group $C$ and 4.1 \pm 1.85 min for group $G, p=0.016$ ), and the total procedure time 


\begin{tabular}{|c|c|c|}
\hline \multicolumn{3}{|c|}{ Appendix 2. Aldrete Recovery Score } \\
\hline & Definition & Score \\
\hline \multirow[t]{3}{*}{ Activity } & Able to move 4 extremities voluntarily or on command & 2 \\
\hline & Able to move 2 extremities voluntarily or on command & 1 \\
\hline & Able to move 0 extremities voluntarily or on command & 0 \\
\hline \multirow{3}{*}{ Respiration } & Able to deep breath and cough freely & 2 \\
\hline & Dyspnea or limited breathing & 1 \\
\hline & Apnea & 0 \\
\hline \multirow{3}{*}{ Circulation } & Blood Pressure $\pm 20 \%$ of Preanesthetic level & 2 \\
\hline & Blood Pressure $\pm 20-50 \%$ of Preanesthetic level & 1 \\
\hline & Blood Pressure $\pm 50 \%$ of Preanesthetic level & 0 \\
\hline \multirow{3}{*}{ Consciousness } & Fully Awake & 2 \\
\hline & Arousable on calling & 1 \\
\hline & Not responding & 0 \\
\hline \multirow{3}{*}{$\mathrm{O}_{2}$ saturation } & Maintains $>92 \%$ on room air & 2 \\
\hline & Needs $\mathrm{O}_{2}$ inhalation to maintain $\mathrm{O}_{2}$ saturation $>90 \%$ & 1 \\
\hline & Saturation < 90\% even with supplemental oxygen & 0 \\
\hline
\end{tabular}

was prolonged in Group G, as well (15.21 \pm 3.15 for group C and $16.64 \pm 2.53$ group $G, p=0.028)$. Complications occurred in 6 patients in Group $G(p=0.011)$. One patient suffered an allergic reaction treated with antihistamines, one patient had bradycardia ( $H R<50$ beats per minute for 30 seconds) treated with 0.5 $\mathrm{mg}$ atropine, four patients had hypersalivation and one patient was desaturated $\left(\mathrm{SpO}_{2}<90 \%\right)$ because of hypersalivation. No complication was observed in Group C (Table 1).

HR was statistically significantly lower at the start and at the 20th minute in Group $G(p=0.036, p=0.001)$ when compared to Group C. In Group C, changes in HR were statistically significantly different between the start, $5^{\text {th }}$ minute, $10^{\text {th }}$ minute and $20^{\text {th }}$ minute values $(p<0.001)$. In Group $G$, changes in HR were statistically significantly different between the start, $5^{\text {th }}$ minute, $10^{\text {th }}$ minute and $20^{\text {th }}$ minute values $(p<0.001)$. HR at $5^{\text {th }}$ minute and $10^{\text {th }}$ minute were not statistically significantly different between the groups (Figure 1).

RSS at $5^{\text {th }}$ minute was statistically significantly lower in Group G compared to Group C $(p<0.001)$. RSS score at $10^{\text {th }}$ minute was statistically significantly higher in Group $G(p<0.001)$. RSS at $20^{\text {th }}$ minute were not statistically significantly different. In Group $C$, RSS at the start, $5^{\text {th }}$ minute, $10^{\text {th }}$ minute and $20^{\text {th }}$ minute values were statistically significantly different $(p<0.001)$. In Group $G$, RSS at the start, $5^{\text {th }}$ minute, $10^{\text {th }}$ minute and $20^{\text {th }}$ minute values were statistically significantly different $(p<0.001)$ (Figure 2$)$.

Endoscopist's satisfaction was significantly lower in Group $G$ compared to Group C $(p=0.049)$. Patient's satisfaction significantly decreased lower in Group G compared to Group C ( $p<$ 0.001) (Figure 3).
Recovery time was not statistically significantly different between the groups $(p=0.318)$. Additional propofol dose was statistically higher in Group G compared to Group C ( $2.2 \pm 0.69$ for group $C$ and $2.58 \pm 0.68$ for group $G, p=0.016$ ) (Table 2).

Total consumption of propofol was not statistically significantly different between the groups. However, Group G received a higher amount of propofol dosage than Group C (145.88 \pm 25.39 for group $C$ and $154.63 \pm 28.85$ for group $G, p=0.154$ ). All procedures were successful in reaching the cecum. Time to reach the cecum was not statistically different between the two groups (Table 3).

\section{DISCUSSION}

BE includes lower and upper GIS endoscopy (colonoscopy and upper endoscopy) proceeded the same day and the same session. Although there is insufficient data regarding indications and frequency of application of $\mathrm{BE}$, iron deficiency anemia, fecal occult blood, dyspepsia and/or pain are the most important indications $(1,2)$.

BE reduces patient's and the physician's loss of time and additionally reduces adverse effects due to sedation (3). In the retrospective study performed by Urquhart et al. (3) the patients who underwent lower and upper GIS endoscopy between 2000 and 2004 for four years in United States of America (USA) were analyzed, and it was determined that a total of 591,074 patients had lower and upper endoscopy and the procedure was performed on the same day and at the same session in 66,265 of them. Thus, the frequency of application of BE in the USA was determined to be $11.2 \%$. Fifty-two point one of the patients 


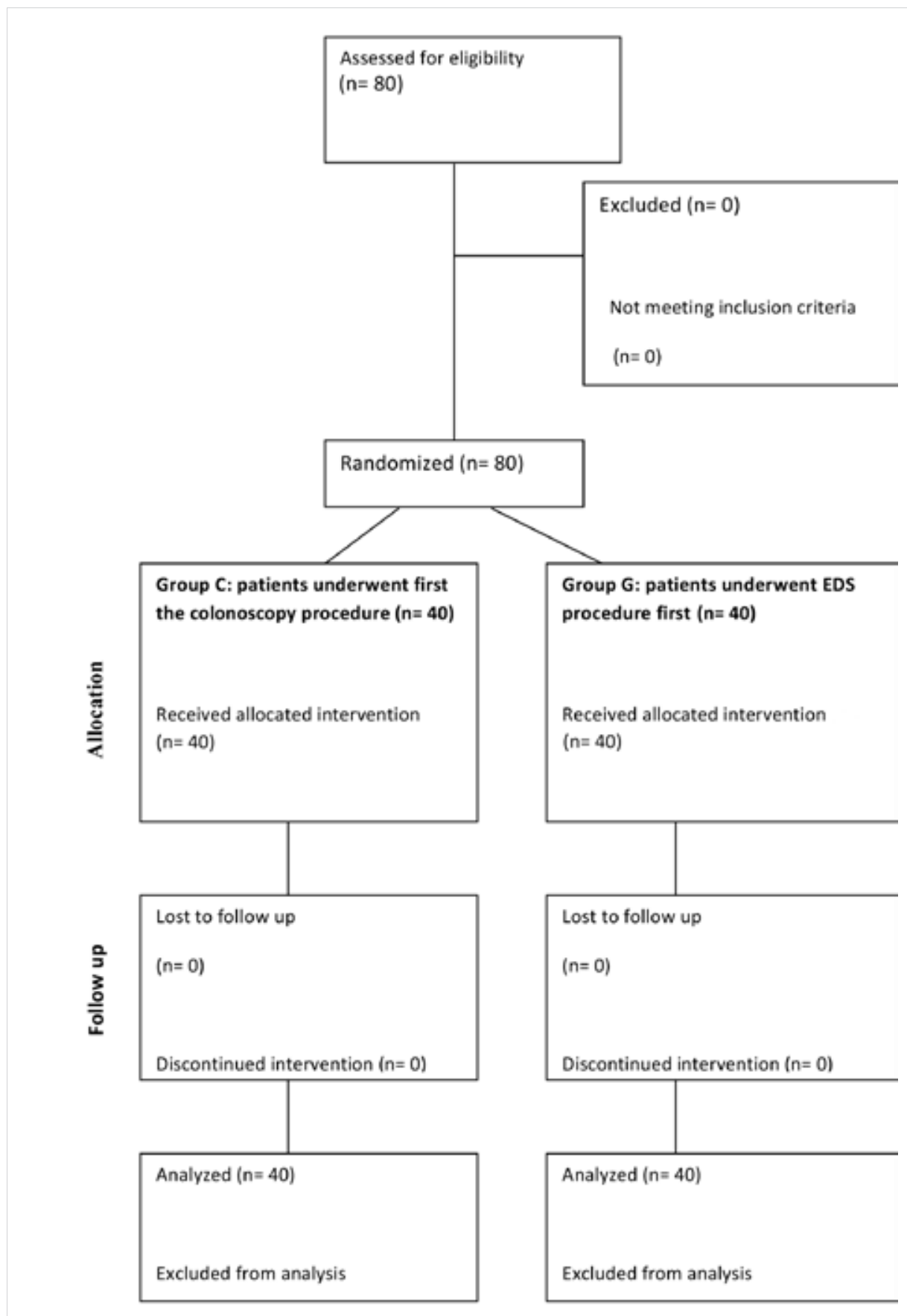

Appendix 3. CONSORT flow diagram.

were females (52.1\%), and mean age of the patients was 60.8 years. In our study, mean age of the patients was 48.7 years, and $48.8 \%(n=39 / 80)$ of the patients were females.

Currently, most endoscopic procedures are performed with sedation. Use of sedation improves success of the procedure, and patient's and physician's comfort, as well $(7,8)$. Additionally, it lowers stress hormone levels (9). For this purpose, benzodiaze- pines, meperidine and propofol are commonly used. Due to the advantages such as rapid onset of action and providing shortterm anesthesia, propofol is the most commonly preferred anesthetic agent for endoscopic procedures in recent years $(7,8)$. In a study performed in our clinic and comparing the use of propofol-fentanyl, propofol-alfentanyl during colonoscopy, the need for additional propofol dose has been found lower and re- 
Table 1. Demographical data, procedure duration, complications

\begin{tabular}{|c|c|c|c|c|c|c|}
\hline \multirow{2}{*}{\multicolumn{2}{|c|}{ Age }} & \multicolumn{2}{|c|}{ Group $C(n=40)$} & \multicolumn{2}{|c|}{ Group G $(n=40)$} & $p$ \\
\hline & & \multicolumn{2}{|c|}{$48.78 \pm 9.53$} & \multicolumn{2}{|c|}{$48.68 \pm 12.22$} & $0.968^{*}$ \\
\hline \multirow[t]{2}{*}{ Sex } & Female n (\%) & 21 & $(52.50 \%)$ & 18 & $(45.00 \%)$ & \multirow[t]{2}{*}{$0.502^{* *}$} \\
\hline & Male n (\%) & 19 & $(47.50 \%)$ & 22 & $(55.00 \%)$ & \\
\hline \multicolumn{2}{|l|}{$\mathrm{BMI}\left(\mathrm{m}^{2} / \mathrm{kg}\right)$} & \multicolumn{2}{|c|}{$26.98 \pm 3.76$} & \multicolumn{2}{|c|}{$26.86 \pm 4.23$} & $0.898^{*}$ \\
\hline \multicolumn{2}{|c|}{ Procedure duration (minutes) } & \multicolumn{2}{|c|}{$15.21 \pm 3.15$} & \multicolumn{2}{|c|}{$16.64 \pm 2.53$} & $0.028^{*}$ \\
\hline \multicolumn{2}{|c|}{ Colonoscopy duration (minutes) } & \multicolumn{2}{|c|}{$9.8 \pm 2.85$} & \multicolumn{2}{|c|}{$10.68 \pm 2.22$} & $0.131^{*}$ \\
\hline \multicolumn{2}{|c|}{ Esophagoduodenoscopy (minutes) } & \multicolumn{2}{|c|}{$3.22 \pm 1.31$} & \multicolumn{2}{|c|}{$4.1 \pm 1.85$} & $0.016^{*}$ \\
\hline \multirow[t]{2}{*}{ Retching } & Yes & 14 & $35.00 \%$ & 13 & $32.50 \%$ & \multirow[t]{2}{*}{$0.813^{* *}$} \\
\hline & No & 26 & $65.00 \%$ & 27 & $67.50 \%$ & \\
\hline \multirow[t]{2}{*}{ Complication } & Yes & 40 & $100.00 \%$ & 34 & $85.00 \%$ & \multirow[t]{2}{*}{$0.011^{* *}$} \\
\hline & No & 0 & $0.00 \%$ & 6 & $15.00 \%$ & \\
\hline
\end{tabular}

* Student t-test; ** Chi-square test, $p<0.05$ statistically significant different, values are mean \pm SD.

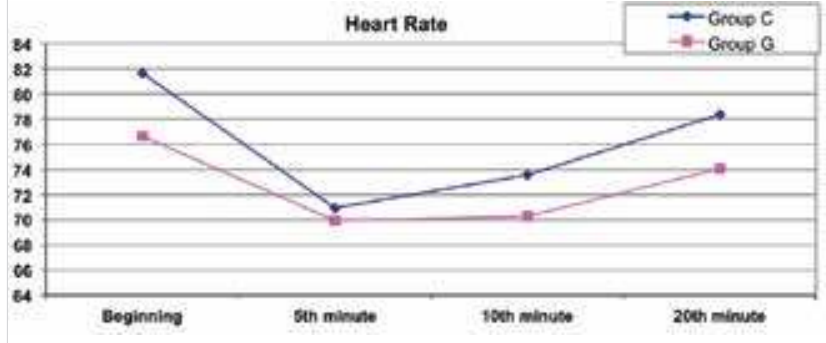

Figure 1. Heart rate (beats per minute).

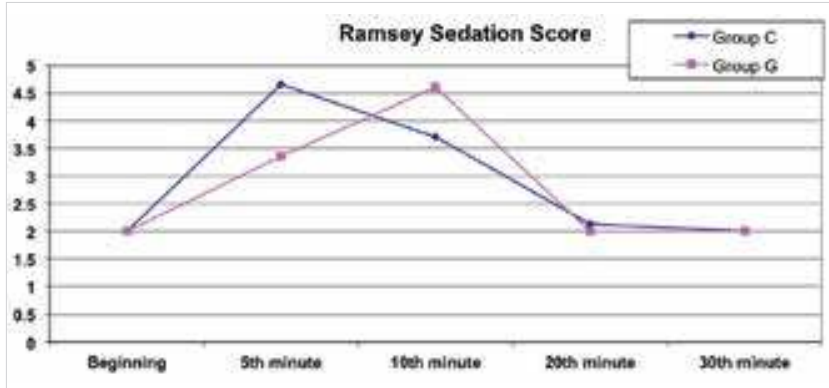

Figure 2. Ramsey sedation score.

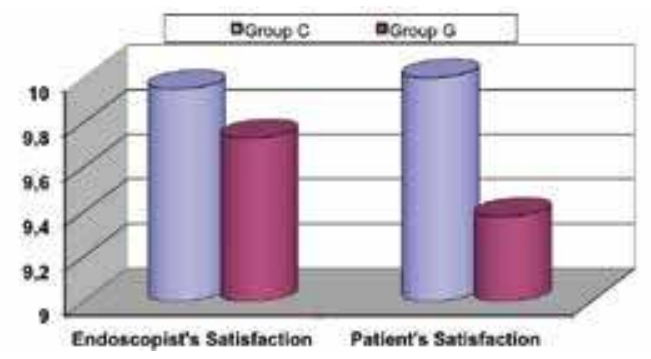

Figure 3. Endoscopist's and patient's satisfaction. covery more rapid in the propofol-fentanyl group $(9,10)$. Therefore, we also preferred to administer propofol-fentanyl combination for sedation in our study.

In our study, we used RSS for the evaluation of the sedation level. It could also be benefited from Bispectral Index Score (BIS) to measure the depth of sedation and reduce the use of sedative drug. There are studies comparing the use of RSS and BIS $(11,12)$. In these studies, it has been emphasized that BIS is a suitable monitorization tool for the patients under sedation and over-sedation and complications related to over-sedation could be prevented by BIS $(11,12)$. However, there are studies indicating that measurements of RSS and BIS are consistent, the amount of sedative drug use does not change $(11,12)$. Not using BIS can be considered the weakness of our study. Which of the examinations (gastroscopy and colonoscopy) will be performed first in BE usually depends on the preference and experience of the endoscopist. While some endoscopists believe that performing gastroscopy first makes the colonoscopy procedure more difficult due to gas insufflation, some endoscopists think that performing colonoscopy first makes the gastroscopy procedure more difficult due to increased bowel motility and the external pressure of the colon on the stomach. However, in recent years, this condition has also been the subject of studies despite in limited number, and it was studied on procedure priority regarding many issues such as procedural success, procedure duration, complications and consumption of sedative agents used (4-6).

In the retrospective study performed by Oner et al. (13), time to reach the cecum has been compared between the patients undergoing colonoscopy alone and the patients undergoing gastroscopy first followed by colonoscopy. The study included two-year data. One thousand six hundred and seventy-two patients underwent colonoscopy alone and three hundred and 
Table 2. Additional propofol dose and recovery time

\begin{tabular}{|l|c|c|c|}
\hline & Group C $(\mathbf{n}=\mathbf{4 0})$ & Group G (n= 40) & p \\
\hline Additional propofol dose & $2.2 \pm 0.69$ & $2.58 \pm 0.68$ & 0.016 \\
\hline Recovery time (minutes) & $1.04 \pm 0.63$ & $1.19 \pm 0.71$ & 0.318 \\
\hline$p<0.05$ statistically significantly different, values are mean \pm SD. & & \\
\hline
\end{tabular}

Table 3. Total propofol consumption and time to reach cecum

\begin{tabular}{|l|c|c|c|}
\hline & Group C (n= 40) & Group G (n= 40) & p \\
\hline Total propofol amount & $145.88 \pm 25.39$ & $154.63 \pm 28.85$ & 0.154 \\
\hline Time to reach cecum (min) & $6.91 \pm 2.15$ & $7.69 \pm 2.09$ & 0.108 \\
\hline$p<0.05$ statistically significantly different, values are mean \pm SD. & & \\
\hline
\end{tabular}

nineteen patients underwent BE. No difference was seen between the two groups regarding the time to reach the cecum. However, endoscopy performance and patient's comfort were found to be better and the need for analgesia was found to be lower in the patients undergoing BE. The authors concluded that performing gastroscopy did not affect the colonoscopy performance negatively and it could be performed in the same session.

Hsieh et al. (4) have searched the answer for the question "which one of gastroscopy and colonoscopy should be performed first in bidirectional endoscopy?" and compared 87 patients undergoing colonoscopy first and 89 patients undergoing gastroscopy first regarding procedure duration, recovery period, patient tolerance, adverse effects and consumption of propofol needed for sedation. Procedure duration, recovery period, adverse effects and patient tolerance have been found similar in both groups, but consumption of propofol and patient movement during procedure have been found higher in the group undergoing colonoscopy first. Total propofol consumed is $135 \mathrm{mg}$ in the group undergoing colonoscopy first and $124 \mathrm{mg}$ in the group undergoing gastroscopy first. This is the most important study focusing on the consumption of sedative agent, and especially, consumption of propofol in BE.

The results of our study indicate that while the number of administration of additional propofol dose was higher in the group undergoing gastroscopy first, no difference was found between the groups regarding consumption of propofol. Total dose of propofol is $145 \mathrm{mg}$ in the group undergoing colonoscopy first and $154 \mathrm{mg}$ in the group undergoing gastroscopy first in our study. No difference was found between the groups regarding recovery period. This condition can be explained by similar total propofol consumptions. RSS showed an increase in both groups beginning from the 5 th minute. RSS values measured in the $5^{\text {th }}$ minutes were lower in the group undergoing gastroscopy first than the group undergoing colonoscopy first. This condition can be explained by gastroscopy duration last- ing approximately 3-4 minutes, position change during colonoscopy procedure in the $5^{\text {th }}$ minutes and increase in awakening with the beginning of colonoscopy procedure. Similarly, RSS values of the group undergoing colonoscopy first showed a decrease in the 10th minute. This condition can be explained by gastroscopy duration lasting 9-10 minutes, position change during colonoscopy procedure in the $10^{\text {th }}$ minute and increase in awakening with the beginning of gastroscopy procedure.

Cho et al. (5) have suggested beginning the procedure first with gastroscopy by stating that beginning the procedure first with gastroscopy followed by colonoscopy reduced the stress level of the patient in BE performed by them in 80 patients without sedation. However, they determined no significant differences regarding procedural success. Choi et al. (6) have performed a new large-scale study focusing on endoscopy performance by stating that the number of patients of the study performed by Cho et al.(5) was insufficient and endoscopy performance was not evaluated sufficiently in the study performed by Hsieh et al. (4) They analyzed 1100 patients undergoing BE regarding colonoscopy performance. They determined no significant differences between performing gastroscopy or colonoscopy first regarding the time to reach the cecum, cecal intubation and the adenoma detection rates. The time to reach the cecum was found to be 6.3 minutes and 6.4 minutes, respectively. Cecal intubation became more difficult in female patients over the age of 55, patients with insufficient bowel cleansing and patients with previous surgery. They stated that procedure priority did not affect procedural success, but performing colonoscopy first followed by gastroscopy disturbed patient comfort. Furthermore, they performed the procedure without sedation in 554 patients. They emphasized that administration of sedation did not change procedural success either but improved patient comfort. In our study, it was observed that gastroscopy duration and total procedure duration were longer in the group undergoing gastroscopy first followed by colonoscopy. However, no significant difference was determined regarding colonoscopy duration. No difference was determined between 
the groups regarding the time to reach the cecum. The time to reach the cecum was found to be 6.9 minutes in the colonoscopy first group followed by gastroscopy and 7.6 minutes in the group undergoing gastroscopy first followed by colonoscopy. The time to reach the cecum in our study was found to be similar to Choi's study.

In the study performed by Carter et al. (14) on 163 patients undergoing bidirectional endoscopy with conscious sedation using i.v meperidine and midazolam, procedure priority of gastroscopy and colonoscopy has been investigated. They have determined no significant difference between two procedures regarding procedure duration, procedural success, the time to reach the cecum, recovery period, need for additional midazolam, pain scores and patient satisfaction. In our study, while endoscopist and patient satisfaction scores were higher in both groups, patient satisfaction and physician satisfaction were found to be better in the group undergoing colonoscopy first.

In the studies performed, adverse effects have not been evaluated. In our study, while no adverse effect was observed in the patient group undergoing colonoscopy first, adverse effect was observed in 6 patients of the group undergoing gastroscopy first. These adverse effects were allergic reaction in 1 patient bradycardia in 1 patient and desaturation occurring due to increased secretion after gastroscopy in 4 patients. No difference was determined between the groups regarding observation of nausea during gastroscopy.

In our study, performing procedures at the same session may cause concerns about contamination, especially when the colonoscopy is implemented before gastroscopy group. Endoscopic infections can be divided into two types: endogenous and exogenous infections. Endogenous infections are most common in endoscopic procedures. This is related to factors such as the patient's immunosuppression or abscess existence. Exogenous infections are less common and can be prevented by endoscope cleaning, disinfection and drying according to a strict protocol. In bidirectional endoscopy, there is no data showing the relationship of the procedure sequence with the infection. We also paid attention to the cleaning of the endoscope in accordance with the recommendation of the guidelines $(15,16)$. In addition, endoscopists changed their aprons and gloves from gastroscopy to colonoscopy and from colonoscopy to gastroscopy. Although there was one of the follow-up parameters absent in our study protocol, no process related infection was reported. However, this subject can guide future studies.

\section{CONCLUSION}

In conclusion, performing colonoscopy first followed by gastroscopy in BE can be preferred since gastroscopy and procedure have a short duration and complication rates and additional propofol doses are lower. However, large-scale studies are required to reply the question, "which one of gastroscopy and colonoscopy should be performed first in bidirectional endoscopy?" regarding anesthesia and procedural success.

Ethics Committee Approval: Local ethics committee approval (28.05.2013/197) was obtained for this study

Informed Consent: Informed consent form was obtained from all patients

Peer-review: Externally peer-reviewed.

Author Contributions: Concept - P.S., Ö.B., H.Ş.T; Design - P.S., C.T.I.; Supervision - S.O., M.M.; Resource - P.S., Ö.B.; Materials - P.S., H.Ş.T.; Data Collection and/or Pro-cessing - C.T.I., P.S.; Analysis and Interpretation - C.T.I., S.O.; Literature Review - S.O., M.M.; Writing Manuscript - H.Ş.T., Ö.B.; Critical Reviews - M.M., S.O.

Conflict of Interest: The authors have no conflicts of interest.

Financial Disclosure: Financial support was provided by departmental sources.

\section{REFERENCES}

1. American Gastroenterological Association. American Gastroenterological Association medical position statement: evaluation and management of occult and obscure gastrointestinal bleeding. Gastroenterology 2000; 118: 197-200. [CrossRef]

2. Hardwick RH, Armstrong CP. Synchronous upper and lower gastrointestinal endoscopy is an effective method of investigating iron-deficiency anaemia. Br J Surg 1998; 85: 1725-8. [CrossRef]

3. Urquhart J, Eisen G, Faigel DO, Mattek N, Holub J, Lieberman DA. A closer look at same-day bidirectional endoscopy. Gastrointest Endosc 2009; 69: 271-7. [CrossRef]

4. Hsieh YH, Lin HJ, Tseng KC. Which should go first during same-day bidirectional endosocopy with propofol sedation? J Gastroenterol Hepato 2011;26: 1559-64. [CrossRef]

5. Cho JH, Kim JH, Lee YC, Song SY, Lee SK. Comparison of procedural sequences in same-day bidirectional endoscopy without benzodiazepine and propofol sedation: starting at the bottom or the top. $J$ Gastroenterol Hepatol 2010; 25: 899-904. [CrossRef]

6. Choi JS, Youn YH, Lee SK, Kim HM, Kim YJ, Han KJ, et al. Which should go first during same-day upper and lower gastrointestinal endoscopy? A randomized prospective study focusing on colonoscopy performance. Surg Endosc 2013; 27: 2209-15. [CrossRef]

7. McQuaid KR, Laine L. A systematic review and meta-analysis of randomized, controlled trials of moderate sedation for routine endoscopic procedures. Gastrointest Endosc 2008; 67: 910-23. [CrossRef]

8. Qadeer MA, Vargo JJ, Khandwala F, Lopez R, Zuccaro G. Propofol versus traditional sedative agents for gastrointestinal endoscopy: a meta-analysis. Clin Gastroenterol Hepatol 2005; 3: 1049-56. [CrossRef]

9. Oei-Lim VL, Kalkman CJ, Bartelsman JF, Res JC, van Wezel HB. Cardiovascular responses, arterial oxygen saturation and plasma catecholamine concentration during upper gastrointestinal endoscopy using conscious sedation with midazolam or propofol. Eur J Anaesthesiol 1998; 15: 535-43. [CrossRef]

10. Türk HŞ, Aydoğmuş M, Unsal O, Köksal HM, Açik ME, Oba S. Sedationanalgesia in elective colonoscopy: propofol-fentanyl versus propofolalfentanil. Braz J Anesthesiol 2013; 63: 352-7. [CrossRef] 
11. Weatherburn C, Endacott R, Tynan P, Bailey M. The impact of bispectral index monitoring on sedation administration in mechanically ventilated patients. Anaesth Intensive Care 2007; 35: 204-8. [CrossRef]

12. Mondello E, Siliotti R, Noto G, Cuzzocrea E, Scollo G, Trimarchi G, et al. Bispectral Index in ICU: correlation with Ramsay Score on assessment of sedation level. J Clin Monit Comput 2002; 17: 271-7. [CrossRef]

13. Oner OZ, Demirci RK, Gündüz UR, Aslaner A, Koç U, Bülbüller N. Prior esophagogastroduodenoscopy does not affect the cecal intubation time at bidirectional endoscopies. Int J Clin Exp Med 2013; 6: 599-602. [CrossRef]

14. Carter D, Lahat A, Papageorgiou NP, Goldstein S, Eliakim R, Bardan E. Comparison of procedural sequence in same-day consecutive bidirectional endoscopy using moderate sedation: a prospective randomized study. J Clin Gastroenterol 2014; 48: 236-40. [CrossRef]
15. McCafferty CE, Aghajani MJ, Abi-Hanna D, Gosbell IB, Jensen SO. An update on gastrointestinal endoscopy-associated infections and their contributing factors. Ann Clin Microbiol Antimicrob 2018; 17: 36. [CrossRef]

16. ASGE Quality Assurance in Endoscopy Committee, Calderwood AH, Day LW, Muthusamy VR, Collins J, Hambrick RD, Brock AS, et al. ASGE guideline for infection control during Gl endoscopy. Gastrointest Endosc 2018; 87: 1167-79. [CrossRef]

\title{
ORIJINAL ÇALIŞMA-ÖZET
}

Turk J Surg 2020; 36 (2): 172-179

\section{Özofagoduedonoskopi veya kolonoskopi: ilk ne yapılmalı?}

\author{
Pınar Sayın ${ }^{1}$, Özgür Bostancı ${ }^{2}$, Hacer Şebnem Türk ${ }^{1}$, Canan Tülay Işıl' ${ }^{1}$ Sibel Oba' ${ }^{1}$, Mehmet Mihmanlı \\ 1 Şişli Etfal Eğitim ve Araştırma Hastanesi, Anesteziyoloji ve Reanimasyon Bölümü, İstanbul, Türkiye \\ 2 Şişli Etfal Eğitim ve Araştırma Hastanesi, Genel Cerrahi Bölümü, İstanbul, Türkiye
}

\section{ÖZET}

Giriş ve Amaç: Özofagoduedonoskopi ve kolonoskopi aynı seansta iki yönlü endoskopi olarak yapılabilir. Bu çalışmanın amacı, iki yönlü endoskopi için ilk kez yapılan özofagoduedonoskopi veya kolonoskopide anestezi gereksinimlerinin ve hemodinamik etkilerinin karşılaştırılmasıdır.

Gereç ve Yöntem: On sekiz-70 yaş arası, "American Society of Anesthesiologists (ASA)" sınıflaması I-III 80 hasta randomize olarak çalışmaya dahil edildi. Hastalar iki gruba ayrıldı; Grup C: Illk kolonoskopi, ardından özofagoduedonoskopi. Grup E: ilk özofagoduedonoskopiyi takiben kolonoskopi yapıldı. Tüm hastalara $1 \mu \mathrm{g} / \mathrm{kg}$ fentanil ve $1 \mathrm{mg} / \mathrm{kg}$ propofol ile standart anestezi uygulandı. Olguların her 10 dakikada bir kalp atım hızı SpO Ramsey Sedasyon Skoru kaydedildi. Toplam propofol tüketimi, özofagoduedonoskopi sırasında öğürme ve çekuma ulaşma zamanı da kaydedildi. Endoskopist ve hasta memnuniyeti sorgulandı.

Bulgular: Özofagoduedonoskopi sırasında öğürme, her iki grupta istatistiksel olarak anlamlı farklı değildi. Grup E'de toplam işlem süresi ve özofagoduedonoskopi süresi istatistiksel olarak anlamlı uzun bulundu. Grup E'de komplikasyon sıklığı arttı. Endoskopist ve hasta memnuniyeti Grup E'de daha düşüktü. Çekuma ulaşma ve derlenmeye kadar geçen sürede fark yoktu. Ek Propofol tüketimi Grup E'de artmıştı.

Sonuç: Prosedür süresinin kısalması, propofol tüketiminin daha az olması ve komplikasyonların azalması sebebiyle, çift yönlü endoskopide işleme kolonoskopi ile başlamak daha iyi bir seçenek olabilir.

Anahtar Kelimeler: Kolonoskopi, gastroskopi, anestezi, hasta memnuniyeti

DOi: $10.5578 /$ turkjsurg. 4275 